\title{
Metabolic balance of manganese in young women
}

\author{
By BARBARA E. McLEOD aNd MARION F. ROBINSON \\ Department of Nutrition, University of Otago School of Home Science, \\ Dunedin, New Zealand
}

(Received 21 fune 1971 - Accepted 6 August 1971)

\begin{abstract}
I. Metabolic balance studies of manganese were made on four young women, using brilliant blue and chromic oxide as faecal markers.

2. Mn concentrations in food, faeces and urine were measured by atomic absorption spectrophotometry.

3. No difference in Mn concentrations was obtained between dry-ashing and wet-digestion for removal of organic matter from food or from faeces.

4. Retentions of $0.05-0.46 \mathrm{mg} \mathrm{Mn} / \mathrm{d}$ were obtained. Dermal and menstrual losses were not measured or allowed for.

5. Unlike most other Mn balance studies reported, the retentions obtained were consistent with the accepted size and stability of the body pool of Mn in healthy adult subjects.
\end{abstract}

Few metabolic balance studies of manganese have been reported and the results from these are bewildering. Except for the study of Kent \& McCance (r94I) on two women, each study has indicated a daily accumulation of $\mathrm{Mn}$ in both normal men and normal women which approaches in a matter of weeks the estimated total body pool of I 2-20 mg Mn (Cotzias, 1958). Schroeder, Balassa \& Tipton (1966) confirmed earlier observations that the concentrations of $\mathrm{Mn}$, characteristic for each tissue, remained remarkably constant after the first few weeks of life. There seemed no tendency to accumulate or lose Mn with ageing beyond the needs for growth.

Retention of an element occurs when the total intake is greater than the total output, and its measurement is dependent upon the accuracy of all experimental procedures. For an element like $\mathrm{Mn}$ which is believed to be poorly absorbed, calculated retentions of up to $63 \%$ of the total intake which have been reported for normal subjects are hardly credible, and are unlikely to be caused solely by an overestimate of the intake. There may be another pathway for the excretion of Mn beyond the major output in the faeces and the almost negligible amounts lost in the urine and from the skin. Cotzias (I962), however, emphasized the difficulties in estimating Mn, the questionable specificity of many of the methods, the ubiquitous nature of $\mathrm{Mn}$, and the ease of contamination at each stage of any analytical procedure.

This study reports the satisfactory use of atomic absorption spectrophotometry for estimation of $\mathrm{Mn}$ in food, faeces and urine, and the measurement of the metabolic balance of $\mathrm{Mn}$ for four young women. 


\section{EXPERIMENTAL}

\section{Balance study}

The young women students, subjects $D, W, G$ and $M$, were four of the subjects in a balance study of the metabolic effects of meal frequency (Swindells, Holmes \& Robinson, I968). Each experiment lasted for $27 \mathrm{~d}$; the experimental regimen was divided into three $6 \mathrm{~d}$ experimental periods $(2,3$ and 4$)$, with a $6 \mathrm{~d}$ preliminary period (I) and a $3 \mathrm{~d}$ after-period (5). A constant amount of food for each day was divided into the appropriate number of meals of equal size; three meals were eaten daily in periods I, 3 and 5 , two meals in period 2 (gorging) and nine meals in period 4 (nibbling). The diet consisted of meat loaf and ice-cream with tea and coffee, and for subjects $G$ and $M$ canned orange juice.

Brilliant blue was used as an intermittent faecal marker for all subjects, and in addition chromic oxide was used as a continuous marker for subjects $\mathrm{G}$ and $\mathrm{M}$. They took one capsule containing $500 \pm 2 \mathrm{mg} \mathrm{Cr}_{2} \mathrm{O}_{3}$ three times daily throughout the study (Sharpe \& Robinson, I970).

Samples of the diet, faeces and urine were collected, stored and pooled as described previously (Swindells et al. 1968; Sharpe \& Robinson, 1970).

\section{Analytical methods}

Mn was determined with a Techtron AA-roo atomic absorption spectrophotometer (Varian 'Techtron Pty Ltd, North Springvale, Victoria, Australia). Diet and faeces were digested with a mixture ( $\mathrm{I}: \mathrm{I})$ of redistilled nitric and perchloric acids. For a comparison of wet- and dry-ashing procedures for Mn determination, samples of meat loaf and faeces were ashed at temperatures below $450^{\circ}$ and the ash was extracted with hydrochloric acid. With each set of determinations, blanks and standard solutions were included and treated similarly, as well as extra samples with added Mn.

The urine for each subject of the study was pooled for each period by mixing equal proportions of their 24 h outputs. Samples of $100 \mathrm{ml}$ were digested in the same manner as food and faeces, after which $\mathrm{I} \mathrm{ml} \mathrm{I00 \%} \mathrm{(w/v)} \mathrm{citric} \mathrm{acid} \mathrm{was} \mathrm{added} \mathrm{to} \mathrm{prevent}$ precipitation of calcium phosphate and the $\mathrm{pH}$ was adjusted to 5.2 with ammonia (Healy, I966). Mn present was then chelated with sodium diethyldithiocarbamate extracted into $4 \mathrm{ml}$ methyl isobutyl ketone (MIBK) and sprayed into the flame. Blanks, standard solutions and further samples of urine with added Mn were treated similarly.

\section{RESULTS}

No difference was obtained between the measurements of Mn concentration whether dry-ashing or wet-digestion was used as the preliminary step for removal of organic matter (Table $\mathrm{I}$ ). Values for recovery of $\mathrm{Mn}$ added to samples of meat loaf and to faeces were within the range of $98-\mathrm{r} 02 \%$ for both procedures. A similar set of results was obtained for analysis of tea and coffee. Dry-ashing was not attempted for urine, as $100 \mathrm{ml}$ were required (before chelation and extraction into $4 \mathrm{ml}$ MIBK) to give sufficient Mn for analysis. Recovery of Mn added to urine varied from roo to 
$102 \%$. Because of the close agreement between the two procedures, wet digestion was chosen because of its ease and speed for subsequent determinations of Mn.

Values for the mean daily intake of Mn by the four subjects are given in Table 2. Subject D ingested the greatest amount of meat loaf, accounting for her higher intake of Mn. The lower daily intakes of Mn for subjects $G$ and $M$ can be explained by the lower concentration of $\mathrm{Mn}$ in the meat loaf eaten by these two subjects, $8 \cdot 2 \mu \mathrm{g} / \mathrm{g}$ dry matter (DM) compared with $9.5 \mu \mathrm{g} / \mathrm{g} \mathrm{DM}$ in the loaf eaten by subjects $\mathrm{D}$ and W. The

\section{Table I. Comparison of wet-digestion and dry-ashing in estimations of manganese in faeces and meat loaf}

(Mean values ( $\mu \mathrm{g} / \mathrm{g}$ dry mattex) with their standard deviations for the number of measurements shown in parentheses)

$\begin{array}{lcc} & \text { Dry-ashing } & \text { Wet-digestion } \\ \text { Faeces } & \text { 17I } \pm 10(8) & 170 \pm \text { I I (6) } \\ \text { Meat loaf } & 9.5 \pm 0.9(6) & 9.5 \pm 0.3(3)\end{array}$

Table 2. Mean daily intake $(\mathrm{mg})$ of manganese by young women from each of the dietary constituents and in total

$\begin{array}{ccccccc}\text { Subject } & \begin{array}{c}\text { Meat } \\ \text { loaf }\end{array} & \begin{array}{c}\text { Ice- } \\ \text { cream* }\end{array} & \text { Tea } & \text { Coffee } & \begin{array}{c}\text { Orange } \\ \text { juice }\end{array} & \begin{array}{c}\text { Total } \\ \text { intake }\end{array} \\ \text { D } & 2.89 & 0 & 0.18 & 0.08 & - & 3.15 \\ \text { W } & 2.62 & 0 & 0.09 & 0.16 & - & 2.87 \\ \text { G } & 2.22 & 0 & 0.23 & - & 0.03 & 2.48 \\ \text { M } & 2.36 & 0 & 0.19 & 0.04 & 0.03 & 2.62\end{array}$

* Ice-cream contributed a negligible amount of $3 \mu \mathrm{g} \mathrm{Mn}$.

ice-cream ( $0.02 \mu \mathrm{g} / \mathrm{g}$ DM) contributed a negligible daily amount of $3 \mu \mathrm{g} \mathrm{Mn}$. Each subject chose the volume and kind of her intake of fluids, which was kept constant from day to day. Soluble tea had about ten times the Mn concentration of soluble coffee, and that of each varied with the brand chosen: $270-380 \mu \mathrm{g} / \mathrm{g}$ for soluble tea and $2 \mathrm{I}-26 \mu \mathrm{g} / \mathrm{g}$ for soluble coffee. The total daily intake from each beverage was similar, however, as more coffee by weight is required than tea to give a palatable drink. Tea and coffee accounted daily for $0.23-0.26 \mathrm{mg} \mathrm{Mn}$, equivalent to $10 \%$ of the total intake.

Table 3 gives the concentrations of $\mathrm{Mn}$ in the pooled faeces for each of the three $6 \mathrm{~d}$ experimental periods using brilliant blue marker. The values ranged between 0.107 and $0.162 \mathrm{mg} / \mathrm{g}$ DM but were of the same order for each subject. The faecal output was calculated from the faecal dried weight derived from marking with brilliant blue. This was further adjusted for subjects $\mathrm{G}$ and $\mathrm{M}$ by the ratio of the $9.0 \mathrm{~g} \mathrm{Cr}_{2} \mathrm{O}_{3}$ ingested during each period to the amount of $\mathrm{Cr}_{2} \mathrm{O}_{3}$ recovered in the faeces (Sharpe \& Robinson, 1970). As had been demonstrated previously for the faecal output of $\mathrm{Ca}$ and $\mathrm{Mg}$, the use of both brilliant blue and $\mathrm{Cr}_{2} \mathrm{O}_{3}$ reduced considerably the variation from period to period in the faecal output of $\mathrm{Mn}$. Unfortunately $\mathrm{Cr}_{2} \mathrm{O}_{3}$ was not used for subjects $\mathrm{D}$ and $\mathrm{W}$.

Total daily urinary excretion of $\mathrm{Mn}$ for each subject and each period is given in 
Table 4. The variations from period to period are insignificant when the urinary excretion is considered in relation to the intake; it was $0.2 \%$ of the intake for subject M and up to $0.7 \%$ for subject D. Values for urinary excretion with those for the faecal output made up the 'total output' of Mn. No correction was made for dermal or for menstrual loss.

Table 3. Faecal manganese concentration and daily faecal output of $M$ n by young women, calculated from the Mn concentration of faeces for each experimental period using brilliant blue or both $\mathrm{Cr}_{2} \mathrm{O}_{3}$ and brilliant blue markers

\begin{tabular}{|c|c|c|c|c|c|c|c|}
\hline \multirow[b]{2}{*}{ Subject } & \multirow[b]{2}{*}{ Faecal marker } & \multicolumn{3}{|c|}{$\begin{array}{l}\text { Mn (mg/g dry matter) } \\
\text { in period }\end{array}$} & \multicolumn{3}{|c|}{ Mn $(\mathrm{mg} / \mathrm{d})$ in period } \\
\hline & & 2 & 3 & 4 & 2 & 3 & 4 \\
\hline D & Brilliant blue & 0.148 & 0.150 & 0.162 & $2 \cdot 42$ & 3.40 & I.94 \\
\hline$w$ & Brilliant blue & $0.1 r_{3}$ & 0.107 & $0 \cdot 103$ & $2 \cdot 05$ & $2 \cdot 88$ & $2 \cdot 3^{6}$ \\
\hline $\mathrm{G}$ & $\begin{array}{l}\text { Brilliant blue } \\
\mathrm{Cr}_{2} \mathrm{O}_{3}+\text { brilliant blue }\end{array}$ & $\stackrel{0.118}{-}$ & $\stackrel{0.114}{-}$ & $\frac{0.120}{-}$ & $\begin{array}{l}2 \cdot 25 \\
2 \cdot 08\end{array}$ & $\begin{array}{l}2 \cdot 37 \\
2 \cdot 11\end{array}$ & $\begin{array}{l}1 \cdot 23 \\
2 \cdot 01\end{array}$ \\
\hline $\mathbf{M}$ & $\begin{array}{l}\text { Brilliant blue } \\
\mathrm{Cr}_{2} \mathrm{O}_{3}+\text { brilliant blue }\end{array}$ & $\stackrel{0.135}{-}$ & 0.135 & 0.149 & $\begin{array}{l}I \cdot 8 t \\
2 \cdot 56\end{array}$ & $\begin{array}{l}2 \cdot 67 \\
2 \cdot 31\end{array}$ & $\begin{array}{l}0 \cdot 86 \\
2 \cdot 38\end{array}$ \\
\hline
\end{tabular}

Table 4. Total daily urinary excretion ( $\mathrm{mg}$ ) of manganese by young women for periods 2, 3 and 4

\begin{tabular}{cccc} 
& \multicolumn{3}{c}{ Mn excretion in period } \\
Subject & 2 & 3 & 4 \\
D & 0.014 & 0.019 & 0.015 \\
W & 0.008 & 0.006 & 0.009 \\
G & 0.007 & 0.013 & 0.012 \\
M & 0.003 & 0.004 & 0.008
\end{tabular}

Table 5. Manganese balances ( $m g / d$ ) for four young women calculated by two methods of deriving faecal output

\begin{tabular}{|c|c|c|c|c|}
\hline \multirow[b]{2}{*}{ Subject } & \multirow{2}{*}{$\begin{array}{l}\text { Marker used to } \\
\text { measure faecal output }\end{array}$} & \multicolumn{3}{|c|}{ Mn balance in period } \\
\hline & & 2 & 3 & 4 \\
\hline $\mathrm{D}$ & Brilliant blue & $0 \cdot 72$ & -0.27 & $I \cdot T 9$ \\
\hline W & Brilliant blue & $0.8 \mathrm{r}$ & -0.02 & 0.50 \\
\hline$G$ & $\begin{array}{l}\text { Brilliant blue } \\
\mathrm{Cr}_{2} \mathrm{O}_{3}+\text { brilliant blue }\end{array}$ & $\begin{array}{r}-0.03 \\
0.39\end{array}$ & $\begin{array}{l}0 \cdot 10 \\
0.36\end{array}$ & $\begin{array}{l}\mathrm{I} \cdot 24 \\
0 \cdot 46\end{array}$ \\
\hline M & $\begin{array}{l}\text { Brilliant blue } \\
\mathrm{Cr}_{2} \mathrm{O}_{3}+\text { brilliant blue }\end{array}$ & $\begin{array}{l}0.80 \\
0.05\end{array}$ & $\begin{array}{l}0.00 \\
0.30\end{array}$ & $\begin{array}{l}\mathrm{I} \cdot 75 \\
0.23\end{array}$ \\
\hline
\end{tabular}

Min balances for the young women were calculated by the two methods for deriving the faecal output (Table 5). Because the intake was constant and the urinary excretion was negligible, the balance of Mn was dependent upon the measurement of the faecal output. There was considerable scatter in the balances for each period when brilliant blue was used as the sole marker but, as in the balances of calcium and magnesium (Sharpe \& Robinson, I970), the variations between periods largely disappeared with 
the additional use of $\mathrm{Cr}_{2} \mathrm{O}_{3}$. The cumulative balances of $\mathrm{Mn}$ were calculated according to the method of Isaksson \& Sjögren (1967), from the beginning of the study until the end of each successive period, using the values in Table 5. This way of expressing results reduced the size of the variations for brilliant blue, and when further corrections were made for recovery of $\mathrm{Cr}_{2} \mathrm{O}_{3}$ an almost constant balance was obtained for subject $\mathrm{G}$ of $0.39,0.38,0.40 \mathrm{mg} / \mathrm{d}$ at the end of periods 2,3 and 4 , respectively, and also for subject $M$ of $0.05,0.18$ and $0.19 \mathrm{mg} / \mathrm{d}$.

\section{DISCUSSION}

The precision of balance studies has been questioned and many workers are critical of the interpretations made from them (Hunscher, I96r; Walker, I962, Hegsted, 1967; Isaksson \& Sjögren, 1967). The results of balance studies of $\mathrm{Mn}$ for normal men and women are summarized in Table 6 . The mere fact that there are so few is indicative of the difficulties in their measurement. Forty-eight of the fifty balances may be considered short-term, lasting for 6-40 d, during which the subjects might have been still adjusting to the experimental regimen, but for most subjects there was little change of diet, apart from the men of Lang, North \& Morse (1965) who consumed vegetarian diets and the two women in the study of Kent \& McCance (194I) who derived half their calories from white or wholemeal flour. Even so, from the calculated retentions of $\mathrm{Mn}$, many subjects would have doubled their body pool of $12-$ $20 \mathrm{mg} \mathrm{Mn}$ by the end of the studies (Schoreder et al. 1966). Long-term balance studies have often indicated a greater retention of nutrients than could be obtained from a difference between measurements of the body pool at the beginning and at the end of the study. Unfortunately such measurements were not made for the two men studied by Tipton, Stewart \& Dickson ( 1969 ), who appeared to have retained about $280 \mathrm{mg}$ or $870 \mathrm{mg} \mathrm{Mn} \mathrm{in} 347 \mathrm{~d}$. Such retentions are doubtful in normal young men, particularly as Mn has been shown not to accumulate in man with increase in age. An average daily retention of $\mathrm{I} \cdot 54 \mathrm{mg}$ ( $4 \mathrm{I} \%$ of the intake) was reported by North, Leichsenring \& Norris (1960) for nine young women students, of similar age and occupation as the four subjects used in the present study. These workers did not have the advantage of the new techniques of atomic absorption spectrophotometry, emission spectrography or neutron activation for estimating Mn in biological materials. Because of the greater sensitivity and freedom from interferences obtained with these techniques, it is now possible to measure the urinary output of $\mathrm{Mn}$ with accuracy.

Gorsuch (I959) compared dry-ashing and wet-digestion for the destruction of organic matter. Dry-ashing was a lengthy process during which losses of Mn by volatilization or even gains by contamination might occur, whereas wet-digestion was shorter but the large amounts of reagents required increased the risk from contamination. Later experiments by Down \& Gorsuch (1967) along with those by Strohal, Lulić \& Jelisavčić ( 1969$)$ using ${ }^{54} \mathrm{Mn}$ suggest that wet-digestion is the technique to be preferred.

In our study both procedures were used for analysis of meat loaf and faeces, the major Mn-containing components of the intake and output, respectively. The close 


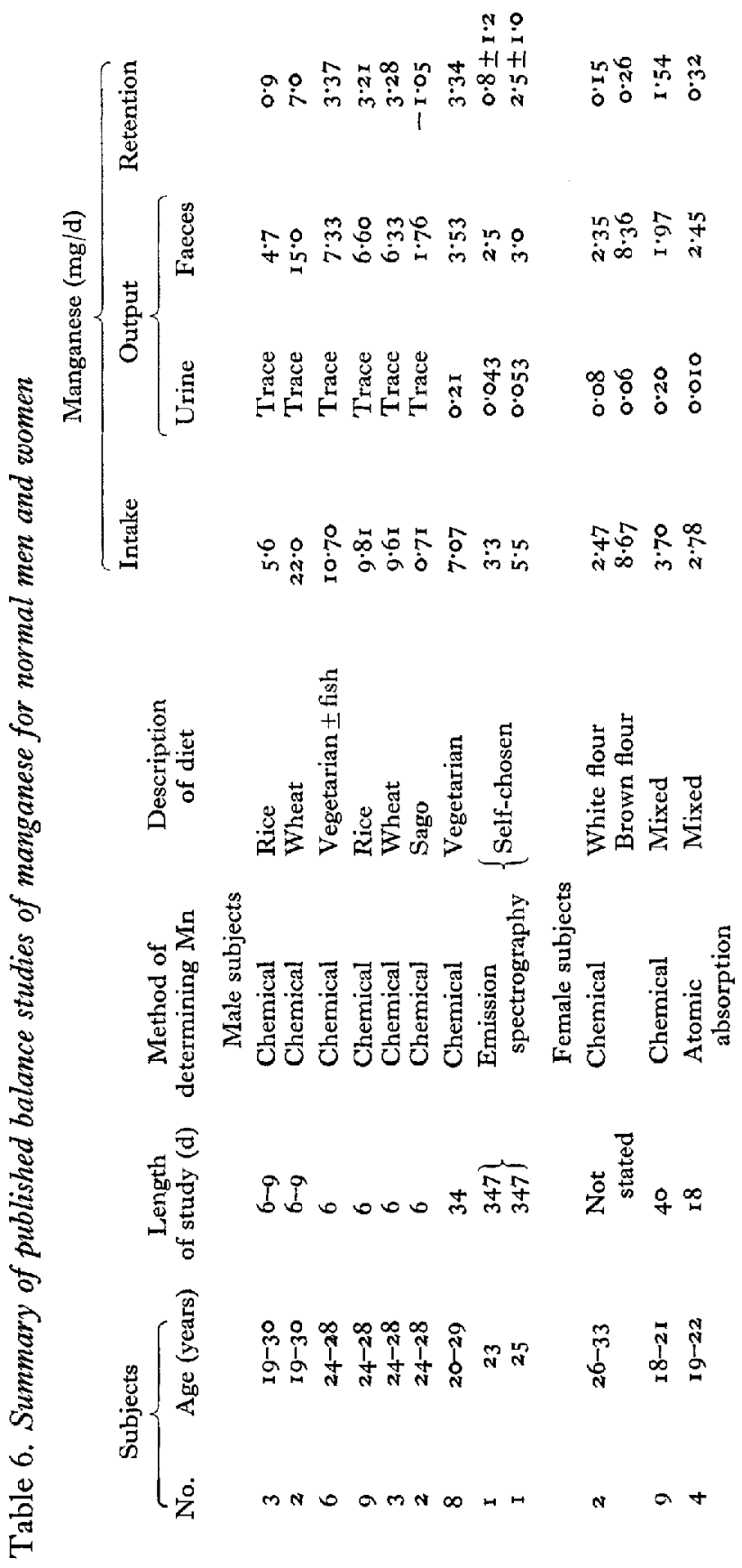

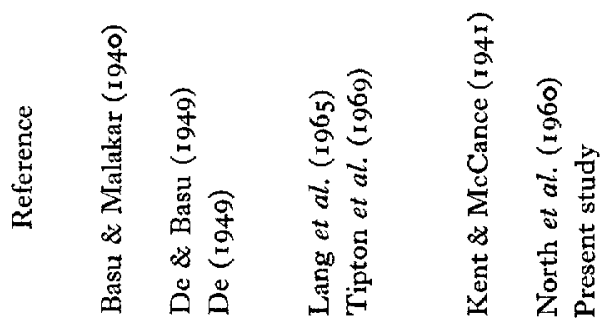


agreement between the results (Table $I$ ) for the two procedures suggests that the precautions taken, such as the careful control of temperature during dry-ashing, the redistillation of acids for wet-digestion and the other measures to reduce contamination from reagents and environment, had reduced the gains and losses of $\mathrm{Mn}$ to negligible values. Cotzias (I962) has pointed out that the trace amounts of Mn found in biological samples tended to be smaller with each analytical improvement, and this may in part be the reason for the lower intake of $\mathrm{Mn}$ by our subjects eating a mixed diet.

The present study is the only one which has used both continuous and intermittent faecal markers together for deriving the faecal output. This reduced the variations from period to period in faecal output and also in 'total output', from which the balance and cumulative balance were derived. However, even with all these improvements, a small daily retention of $\mathrm{Mn}$ was indicated, equivalent to $12 \%$ of the intake. These subjects also appeared to have small retentions of calcium, magnesium, zinc and copper (Sharpe \& Robinson, 1970; McKenzie, 1969). The similarity in the apparent retentions of these elements might be caused by incomplete assessment of the output along with an overestimate of the intake (Hegsted, 1967 ), and further work is required on the measurement in balance studies of dermal and menstrual losses.

We are particularly grateful to the subjects for their willing co-operation, and to Mr L.M. Cantwell for his assistance at all times. This work was supported by the New Zealand Medical Research Council, and the equipment was provided by the Research Committee of the New Zealand University Grants Committee and by the Nuffield Trustees. To all concerned we express our thanks.

\section{REFERENCES}

Basu, K. P. \& Malakar, M. C. (1940). F. Indian chem. Soc. 17, 317.

Cotzias, G. C. (1958). Physiol. Rev. 38, 5०3.

Cotzias, G. C. (1962). In Mineral Metabolism Vol. 2, Part B, p. $40_{3}$ [C. L. Comar and F. Bronner, editors]. New York: Academic Press.

De, H. N. (1949). Indian F. med. Res. 37, 301.

De, H. N. \& Basu, K. P. (1949). Indian f. med. Res. 37, 213.

Down, J. L. \& Gorsuch, T. T. (1967). Analyst, Lond. 92, 398.

Gorsuch, T. T. (1959). Analyst, Lond. 84, 135.

Healy, W. B. (1966). Analytica chim. Acta 34, 238.

Hegsted, D. M. (1967). F. Am. diet. Ass. 50, 105.

Hunscher, H. A. (1961). F. Am. diet. Ass. 39, 209.

Isaksson, B. \& Sjögren, B. (1967). Proc. Nutr. Soc. 26, to6.

Kent. N. L. \& McCance, R. A. (I94I). Biochem. F. 35, 877.

Lang, V. M., North, B. B. \& Morse, L. M. (1965). F. Nutr. 85, 132.

McKenzie, J. M. (1969). Studies of the metabolic balance of zinc and copper in four young women. MHSc Thesis, University of Otago.

North, B. B., Leichsenring, J. M. \& Norris, L. M. (1960). F. Nutr. 72, 217.

Schroeder, H. A., Balassa, J. J. \& Tipton, I. H. (1966). J. chron. Dis. r9, 545.

Sharpe, S. J. \& Robinson, M. F. (1970). Br. Y. Nutr. 24, 489.

Strohal, P., Lulić, S. \& Jelisavčić, O. (1969). Analyst, Lond. 94, 678.

Swindells, Y. E., Holmes, S. A. \& Robinson, M. F. (1968). Br. J. Nutr. 22, 667.

Tipton, I. H., Stewart, P. L. \& Dickson, J. (1969). Hlth Phys. 16, 455.

Walker, A. R. P. (1962). Am. \%. clin. Nutr. 10, 95 . 